Social Exchanges as Motivators of Hotel Employees' Organizational Citizenship Behavior:

The Proposition and Application of a New Three-Dimensional Framework

\author{
Emily Ma* \\ Lecturer \\ Department of Tourism, Leisure, Hotel and Sport Management \\ Griffith University, Nathan Campus \\ Office 0.27, N72 Business 2 \\ Queensland 4111, Australia \\ E-mail: emily.ma@griffith.edu.au \\ Phone: +61 737356554
}

Fax: +61 737356743

Hailin Qu

Regents Professor and William E Davis Distinguished Chair

School of Hotel and Restaurant Administration

Oklahoma State University, Stillwater, OK74078

E-mail: h.qu@okstate.edu 


\title{
Social Exchanges as Motivators of Hotel Employees' Organizational Citizenship Behavior: The Proposition and Application of a New Three-Dimensional Framework
}

\begin{abstract}
This study developed and empirically tested a three-dimensional framework of Organizational Citizenship Behavior (OCB) in the hotel industry. Using a social exchange perspective, the study expanded social exchange theory's emphasis on leader-member exchange to include coworker exchange and customer-employee exchange. The three types of social exchanges were tested as motivators for three types of OCB; organizational, interpersonal and customer. The findings support the distinctiveness of the three types of OCB and the importance of social exchanges as motivators for OCBs. This study contributes to the literature on OCB dimensionality in service organizations, as well as social exchange theory's application to discretionary performance in the hotel industry.
\end{abstract}

Keywords: OCB-O, OCB-I, OCB-C, Social Exchange

\section{Introduction}

\subsection{A Challenge Facing the Hotel Industry}

The hotel and motel industry is a significant contributor to the global service economy. In the United States (U.S.), the hotel and motel industry includes approximately 30,000 companies, generating over $\$ 90$ billion in revenue annually (Research and Market, 2008). In the Asia-Pacific region, especially in China, has been witnessing the fastest growth (Research and Market, 2008). Unlike other industries, the hotel industry is unique in that its core product is intangible service. 
The importance of service quality to a hotel is as critical as the importance of product quality to a manufacturer, because providing high quality service is the starting point of creating satisfied customers. In return, satisfied customers have a stronger tendency to purchase more products and become loyal customers of the hotel (Bienstock, Demoranville and Smith, 2003). Return customers and positive word-of-mouth increase occupancy rates, and support hotel profitability and market share. Hence creating high quality service is essential to the success of any hotel.

Although service quality has been identified as a key factor for hotels’ success, delivering quality service is still one of the major challenges facing hotel managers in the $21^{\text {st }}$ century (Lazer and Layton, 1999). This challenge is a function of two factors: variability and rising expectations.

First, service has unique features, which include intangibility (Bateson, 1977; Lovelock, 1981), heterogeneity (Booms and Bitner, 1981), and inseparability (Carmen and Langeard, 1980) between production and consumption. In the hotel context, service is delivered by frontline employees who serve customers, usually face-to-face. How employees interact with customers determines to a great extent how customers perceive the service quality. Due to each individual employee's uniqueness in terms of personality, attitudes and skills, the quality of service that employees deliver can hardly be consistent. Additionally, hotel service is a highly interactive process, and both employees' and customers' physical well-being and moods could influence the service experience. Therefore, even the same employee’s service performance may fluctuate across time and customer interactions.

Second, as people have become more aware of the importance of service, hotel guests have become more difficult to satisfy. According to Zeithaml (1987), customers' perceptions of 
service quality result from a comparison between the services received and the expectations held. When the service experience meets or exceeds the customers' expectations they feel satisfied; if not, they feel dissatisfied. A satisfying experience will raise a customer's expectations, which makes it more difficult to satisfy the customer in the next service circumstance. As more hotels start to realize the importance of service quality, and the competition among hotels becomes fiercer, today’s customers have more choices and stronger bargaining power than ever before. Therefore, it is becoming more difficult to satisfy customers if hotel employees do only what is required by the job description, task list or policy manual. Rather, excellent service requires employees to go "above and beyond" established routines in order to meet and exceed customers' expectations.

\subsection{OCB as a Possible Solution for the Challenge}

Fortunately, hotel employees often are willing to go "above and beyond" in order to satisfy customers. These "organizational citizens" may include a front office agent who treats a customer with special care because the customer is sick; a housekeeper who helps a new housekeeper to finish her assigned rooms; a restaurant waitress who helps store the leftover food in the refrigerator, to name but a few. All these are examples of employees who perform Organizational Citizenship Behaviors (OCB), which are individual contributions in the workplace that exceed role requirements and are not contractually rewarded job achievements (Bateman and Organ, 1983; Smith, Organ and Near, 1983). In these “organizational citizens” we see hope of overcoming the challenges of delivering quality service to customers. 
However, not all hotel employees are willing to go "above and beyond" requirements. The question then becomes what motivates employees to engage in OCB? Although OCB research has been popular in the management and organizational behavior disciplines for several decades, relatively less attention has been paid to the hospitality industry, especially in the hotel setting. There are theoretical and empirical questions that need to be answered to fully understand OCB in the hotel setting.

The first gap is the lack of an appropriate measure of OCB developed for the hotel setting, and incorporating service industry requirements. Yet such a framework is essentially important because: 1) Hotel industry differs in nature compared to other organizations in which intangible services and constant customer-employee exchanges are important components of its daily operations; 2) OCB studies gain popularity in the hospitality discipline; frameworks of both OCB and its motivators must evolve from their foundations in manufacturing toward service interactions. Currently used regarding OCB were mainly borrowed from other disciplines, which may not be able to capture the unique nature of the hospitality industry.

A second gap is that although social exchange has been proposed and validated as an important antecedent of OCB, only leader-member exchange has drawn significant and sustained research attention (e.g. Konovsky and Pugh, 1994; Organ et al., 2006; Euwema, Wendi and Emmerik, 2007). Hotel employees, however, do not just interact with their leader (supervisor); they interact most often - and most impactfully - with coworkers and customers. Therefore, attention is needed to the additional two types of social exchanges, coworker exchange and customer-employee exchange. Addressing these additional forms of social exchanges in the workplace would enrich social exchange theory in its application to OCB, and would be more 
meaningful for the hotel industry. Considering the significance of studying OCB in the hotel setting as well as the theoretical gaps in OCB studies, the purposes of this study include:

1. To develop and empirically test an expanded theoretical framework for the dimensionality of OCB which incorporates customer-targeted OCB;

2. $\quad$ To develop and empirically test a model of hotel employees' OCB motivation for OCB using three types of social exchange

\section{Theoretical Framework}

\subsection{The Concept and Dimensionality of Organizational Citizenship Behavior}

Organizational citizenship behavior (OCB) refers to individual contributions in the workplace that go above and beyond role requirements and contractually rewarded job achievements (Bateman and Organ, 1983; Smith, Organ and Near, 1983). OCBs are beneficial to organizations, especially to hotels where satisfying customers requires meeting and exceeding their expectations on a constant basis. If all employees could perform OCBs, delivering high quality services and satisfying customer would be less of a challenge.

Although researchers hold different views regarding the dimensionality of OCB, they generally agree that OCB is a multidimensional construct (e.g., Graham, 1989; Moorman and Blakely, 1995; Organ, 1988; Podsakoff, MacKenzie, Moorman and Fetter, 1990; LePine, Erez and Johnson, 2002). Yet, perspectives on the dimensionality of OCB have diverged.

The literature categorizes the dimensions of OCB using two approaches: 1) based on the types of behaviors included (e.g. Organ, 1988; Organ et al, 2006; Van Dyne et al, 1995); or 2) 
based on the targets of citizenship behaviors (e.g. Williams and Anderson, 1991; Bettencourt and Brown, 1997).

For the first approach, Organ’s (1988) five-dimensional framework of OCB has become the most widely used one. According to Organ (1988), there are five dimensions of OCB, including: (1) Altruism, behaving in a way that demonstrates selflessness and concern for the welfare of others; (2) Conscientiousness, evidencing commitment to high levels of work quality and completion; (3) Sportsmanship, choosing not to complain or act in negative ways; (4) Courtesy, taking actions that help prevent problems from occurring, or taking actions in advance to mitigate a problem, and (5) Civic virtue, adopting a posture of "responsible, constructive involvement in the political or governance process of the organization” (Organ, et al., 2006, p. 24). This focus dominates the research literature, with sets of behaviors extended (Van Dyne et al, 1995) or adapted to other cultural contexts (Farth, Earley \& Lin, 1997; Law, Wong \& Chen, 2007)

Research that focuses on the targets of OCB is more limited, but dates to the establishment of the construct. Smith, et al. (1983) conducted a factor analysis on the attributes of OCBs, and generated two factors: altruism and generalized compliance. Williams and Anderson (1991) further classified the two factors as (1) OCB-O, which refers to OCBs that benefit the organization in general and (2) OCB-I, which refers to OCBs that direct primarily to individuals (employees) within the organization.

In fact, the two ways of categorizations are inter-correlated. Williams and Anderson's (1991) work relies heavily on the behavior-based work of Organ, Smith and others. The framework of OCB-O, for example, includes the Conscientiousness, Sportsmanship and Civic 
Virtue dimensions of Organ's (1988) framework, while OCB-I includes the remaining Altruism and Courtesy dimensions.

\subsection{Justification of an expanded framework for $O C B$}

Initially, the majority of research on OCB was conducted in organizations in which customer service was not a major component of the organizations' daily operation. Indeed, Borman and Motowidlo (1993) suggested that traditionally identified OCBs might not be suitable for service-oriented organizations, because these organizations may have special requirements for OCB dimensions related to dealing with customers. Other researchers also agreed that attention should be paid to customer and service oriented citizenship behaviors of customer-contact employees (e.g. Borman and Motowidlo, 1993; Podsakoff and MacKenzie, 1997) rather than just the internal operational focus of the mainstream OCB literature.

To address the particular context and requirements of service organizations, Bettencourt and Brown (1997) identified three dimensions of service oriented OCB. The importance of treating service oriented OCBs separately was also supported by Bettencourt, Gwinner and Meuter (2001), who combined previous OCB measurement (Mackenzie, Podsakoff and Fetter, 1993; Moorman and Blakely, 1995) and service quality measurement (Parasuraman et al., 1988), to develop a three-dimensional service oriented OCB measurement scale. Since service-oriented OCB targets customers, we would refer to this scale as reflecting OCB-C (represents customers), to differentiate it from OCB-I and OCB-O (Williams and Anderson, 1991)

Previous researchers have used the targets of OCBs to categorize the dimensions of the OCB construct (e.g. Williams and Anderson, 1991), and OCB-O and OCB-I have been identified 
and proved as valid constructs (e. g. Moorman and Blakely, 1995). In addition, previous researchers have noted the importance of service oriented OCBs. Efforts made by previous researchers helped to build a sound theoretical foundation for incorporating OCB-C into the existing OCB-O and OCB-I framework. Therefore, this study integrates prior research to utilize a three-dimensional framework of OCB, with OCB-O, OCB-I and OCB-C (see Figure 1).

***Please Insert Figure 1 Here***

\subsection{Social Exchange as Motivator of Employees' OCB}

Researchers suggest that OCB is a complex behavior that can be influenced by demographic factors (Ford \& Richardson, 1994), personality traits (Konovsky and Organ, 1996; Elanain, 2007) and contextual factors (Chonko and Hunt, 2000; Baker, Hunt and Andrews, 2005). Of the many factors that have been investigated, social exchange has been repeatedly found to be an important motivator for employees' OCBs (e.g. Cho and Johanson, 2008; Podsakoff, MacKenzie, Paine and Bachrach, 2000).

The social exchange theory grew out of the disciplines of economics, psychology and sociology (Homans, 1958). In his seminal writing on social exchange, Homans (1958, p. 606) noted that:

"Social behavior is an exchange of goods, material goods but also non-material ones, such as the symbols of approval or prestige. Persons that give much to others try to get much from them, and persons that get much from others are under pressure to give much to them." 
Blau (1986) further defined social exchange as voluntary actions of individuals that are motivated by the returns they are expected to bring from others, as well as social exchanges form relationships. Similar to economic exchange, social exchange generates an expectation of some future return for contributions; however, unlike economic exchange, the exact nature of that return is unspecified. Furthermore, social exchange does not occur on a quid pro quo or calculated basis, but based on individuals' trusting that the other side of the exchanges will fairly fulfill their obligations in the long run (Holmes, 1981). Social exchange theory explains how we feel about a relationship with another person based on our perceptions of: 1) the balance between what we put into the relationship and what we get from it; 2) the kind of relationship we deserve; and 3) the chances of having a better relationship with someone else.

Social exchange theory has been used to explain the various phenomena and processes that occur in organizations, including OCBs (e.g. Tsui, Pearce, Porter and Tripoli, 1997; Tsui and Wu, 2005; Van Dyne and Ang, 1998). For example, social exchange theory has been used to explain the relationship between employees and the organization (Tsui et al., 1997; Van Dyne and Ang, 1998). Employers utilizing the social exchange approach seek a long-term relationship with employees and show concern about employees' well-being and career development, and expect the concern and commitment to be reciprocated. From the social exchange perspective, if an employee is treated with respect they would be more likely to engage in OCBs (Cho and Johanson, 2008). Researchers also found that leaders' and supervisors' support can lead to employee citizenship behavior because a social exchange relationship is developed between employees and their supervisors (Organ, 1988; Podsakoff, MacKenzie, Paine and Bachrach, 2000). Similar findings have also emerged in the context of coworkers' social exchange (Ilies, Nahrgang and Morgeson, 2007; Rhodes and Eisenberger, 2002). 
In the hotel setting, frontline employees may have social exchanges with three groups of people, namely supervisors or leaders, coworkers and customers. Respectively, they are named as 1) Leader-Member exchange (LMEX), 2) Coworker exchange (COEX) and 3) Customeremployee exchange (CEEX). As noted above, Leader-Member exchange has received greater research attention relative to the other two types of social exchanges (Organ et al., 2006), as we might expect in the general management literature. Yet attention to coworker exchange and customer-employee exchange is desired and important in the hotel industry for at least two reasons. First, hotel employees are not working independently. Rather, the creation of high quality service relies greatly on the teamwork of hotel employees. Therefore, many interactions among coworkers occur in the process of customer services. Secondly, serving customers is considered the most important task for hotel employees. However, customers are not passive recipients of the service; they are actively involved in it (Sierra and McQuitty, 2005). Therefore, the success of the service experience relies greatly on the active participation of customers. By treating the exchanges between coworkers and between customers and employees as a social exchange process, this study expands social exchange theory's application to OCB and service industries (Figure 2).

\section{***Please Insert Figure 2 Here ${ }^{* * *}$}

According to social exchange theory, "persons that get much from others are under pressure to give much to them" (Homans, 1958, p. 606), and this "giving back" usually happens in the form of various OCBs, as if these behaviors were required it would not be seen as reciprocation. In addition, employees are expected to have stronger reciprocal behaviors to the source of the treatment (Scott, 2007). This leads to employees performing OCBs to different targets (organization, coworker and customer). Moreover, if employees experience positive 
social exchanges with leaders, coworkers and customers, they may tend to engage in various types of OCBs related to those social exchanges; that is positive exchanges with customers may increase the level of OCB-C. However, OCBs may not necessarily be direct only to that specific target of social exchange. There may be spillover effects for positive social exchanges such that positive exchanges in one sphere also result in enhanced OCBs on the two other domains. For example, employees who have positive exchanges with their supervisor may exhibit more OCBs with coworkers and customers. Employees may also engage in OCB-I and OCB-O as a result of positive social exchanges with customers.

\subsection{Conceptual Model and Hypotheses}

Based on the literature review, the following conceptual model and hypotheses are proposed on the relationships between the three types of social exchanges (Leader-member Exchange, Coworker Exchange and Customer-employee Exchange) and the three types of OCBs (OCB-O, OCB-I and OCB-C).

\footnotetext{
***Please Insert Figure 3 Here***
}

H1: Leader-member Exchange is positively related to employees' OCB-O.

H2: Coworker Exchange is positively related to employees' OCB-I.

H3: Customer-employee Exchange is positively related to employees' OCB-C.

H4: Leader-member Exchange is positively related to employees' OCB-I;

H5: Customer-employee Exchange is positively related to employees' OCB-O;

H6: Employees' OCB-I is positively related to employees' OCB-C. 


\section{Methodology}

\subsection{Instrument Development}

\subsubsection{Structure of the Questionnaire}

The questionnaire was developed based on previously identified measurements, which was comprised of four sections. Section I was designed to collect hotel employees' work-related information. Section II was designed to collect employees’ perception of the three types of social exchanges (Leader-member, Coworker and Customer-employee) that they experience in their hotels. Section III collected information on hotel employees' performance on the three types of OCBs (OCB-O, OCB-I and OCB-C). For Section II and Section III, the respondents were asked to rate their perception on a seven-point Likert-type scale (where 1=Strongly Disagree and 7=Strongly Agree). Section IV collected demographic information.

\subsubsection{Scale Development}

Two types of social exchanges, Leader-Member Exchange and Coworker Exchange have previously established measurement scales. Leader-Member Exchange was measured using 6 items from Graen and Uhl-Bien (1995). Coworker Exchange was measured using 6 items from Ladd and Henry (2000). The statements are listed in Table 1.

Although Customer-Employee exchange has been recognized as an important type of social exchange, no measurement scale has been established (Sierra and McQuitty, 2005). According to the affect theory of social exchange, customers share some degree of responsibility in the social exchange process. Therefore customers' emotional as well as behavioral responses would influence employees' perceptions and service performance (Lawler, 2001). Sierra and 
McQuitty (2005) suggested that the social exchanges between customers and employees should have an emotional component and a satisfaction component. In addition, Lerman (2006) also suggested that the politeness of customers played an important role in creating a successful experience.. Further, Sierra and McQuitty (2001) suggested that a successful or unsuccessful service experience will impact both the customer and employees’ perception and performance. Using the existing literature (Sierra and McQuitty, 2005; Lawler, 2001; Lerman, 2006), this study developed a Customer-Employee Exchange scale comprised of 5 items. The scale addressed three aspects in the social exchange process: politeness (2 items), satisfaction (2 items) and emotional response (1 item), and is measured from the employees' perspective. The statements are listed in Table 1.

OCB-O was measured by using eight items from Williams and Anderson (1991); OCB-I was measured by using six items from Williams and Anderson (1991); and employees' OCB-C was measured by using eight items from Lin et al. (2008).

\subsubsection{Measurement Validation}

A focus group was conducted to check the face validity and content validity (Churchill and Brown, 2006) of the questionnaire. A total of eight people participated in the focus group, and the participants included hospitality faculty members, supervisory and front-line hotel employees. Modifications to phrasing were made based on feedback from the focus group. The questionnaire was then pilot tested with 34 employees of a hotel in a Midwestern city of the U.S. The Cronbach’s alphas of the six constructs ranged from .721 to .929 (Table 1), suggesting good measurement reliability (Nunnally and Berstein, 1994).

\footnotetext{
***Please Insert Table 1 Here***
} 


\subsection{Sampling and Data Collection}

The major propose of the study is to test a theoretical model. A structured convenience sampling method was used for data collection. This study was designed to use Structural Equation Modeling (SEM) for data analysis, and a total of 37 indicators were used to measure the six latent variables. As suggested by Stevens (2002), at least 10 respondents per indicator are needed for using SEM analysis, leading to a minimum of sample size of 370.

The survey was conducted in China and the questionnaire was translated in Chinese by using the translation/back translation procedure as described by Brislin (1976). Hotels from seven cities in China (Guangzhou, Beijing, Hangzhou, Shenzhen, Baoding, Shijiazhuang and Guilin) agreed to participate in the survey. The data collection was conducted from September to October, in 2009. Six hundred questionnaires were distributed to those hotels, and 407 valid responses were available for data analysis, representing a usable response rate of $67.8 \%$.

\subsection{Data Analysis}

Descriptive data analysis, Confirmatory Factor Analysis (CFA) and Structural Equation Modeling (SEM) were performed by using SPSS 17.0 and LISREL 8.80. Descriptive analysis was used to get a general profile of the respondents. CFA was used to validate the threedimensional framework of OCBs, and SEM was used to test the proposed hypotheses.

\section{Findings}

\subsection{Demographic Profile and Work-related Information of Participants}


The demographic profile and work-related information of the hotel employees who responded to the survey are summarized in the following Table 2. Table 2 shows that of the demographic profile of the respondents is similar to that in most surveys of front-line staff in hotels; most are part-time, younger and female. The minority hold a university qualification. 407 respondents, 323 (79.4\%) are part-time hotel employees and 67 (16.5\%) are full-time employees. 122 (30\%) employees are working in the Housekeeping Department, followed by Food \& Beverage (53: 13\%), Front Desk (42: 10.3\%), Human Resource Management (42: 10.3\%) and Sales \& Marketing (28: 6.9\%). In terms of gender distribution, 266 are female (65.4\%), and 123 are male (30.2\%). The majority of the respondents are between 18-29 years old (56.8\%), and only 14 are over 50 (3.4\%). In terms of education, only 109 employees (26.7\%) obtained bachelor degrees, and the rest of them did not.

\section{***Please Insert Table 2 Here***}

The Mean, Standard Deviation and correlations of demographic variables, including Length of Working, Gender, Age, Education and Income, are summarized in Table 3. According to these results, older employees worked in their hotels longer and also earn higher income. Employees with higher education level earn higher income.

\section{***Please Insert Table 3 Here***}

\subsection{Correlations of Latent Variables}

The Mean, Standard Deviation and correlations of the six latent constructs are summarized in Table 4. The means of the social exchange measures ranged from 5.30 to 5.51 
and the Std. Deviations ranged from 0.87 to 1.03 . The means of the OCB measures ranged from 5.81 to 5.98 and the Std. Deviation ranged from 0.67 to 0.73 . The bivariate correlations showed that the three types of social exchanges were significantly positively related to the three types of OCBs (significant at $\mathrm{p}<0.01$ ).The correlation coefficients ranged from 0.328 to 0.752 , suggesting moderate to strong correlations among the latent variables (Hair et al., 2006).

***Please Insert Table 4 Here***

\subsection{Confirmatory Factor Analysis for the Three-dimensional Framework of OCB}

Confirmatory factor analysis (CFA) was performed to test the model fit and the reliability of the three-dimensional OCBs measurement framework. The model fit indexes (Reisinger and Turner, 1999; Brentler, 1990) are summarized in Table 5. In CFA, the overall model fit refers to the degree to which the specified indicators represent the hypothesized latent construct. As suggested by Brentler (1990), a CFI value $>0.90$ is considered good; CFI $>0.93$ is better and CFI > 0.95 is great. Table 5 shows that the overall fit indices of the three-dimension model of OCB are generally good.

\section{***Please Insert Table 5 Here***}

The reliability of the scale was tested via Convergent Reliability (CR), which assesses the internal consistency of a measure (Fornell and Larcker, 1981), and a CR value of 0.70 or greater is considered good (Hair et al., 2006), with a threshold of 0.6 (Diamantopoulos and Siguaw, 2000). The CR value for OCB-O was 0.89 and the CR value for OCB-I and OCB-C was 0.94, supporting a finding of high internal scale consistency. 
The reliability of the scale was also assessed through the Variance Extracted Estimate (AVE) values. AVE measures the amount captured by a construct in relation to the variance due to random measurement error (Fornell and Lacker, 1981), and AVE > 0.5 indicates that the validity of both the construct and the individual variables are high (Hair et al., 2006). The AVE value for OCB-O was 0.58; the AVE value for OCB-I was 0.66 and the AVE value for OCB-C was 0.68 . This indicated robust representation of the latent constructs. The results of factor loadings, t-values, CR and AVE values are summarized in Table 6.

***Please Insert Table 6 Here***

To summarize, considering both the model fit indices and the factor loading, CR and AVE values, the proposed three-dimensional framework of OCB fits this data well. The framework appears both valid and reliable. The result supported that using the targets of OCB, and separating OCB into OCB-O, OCB-I and OCB-C is an empirically suitable as well as meaningful framework for the hotel industry.

\subsection{Structural Equation Modeling and Hypotheses Testing}

The overall model fit indices of the structural portion of the model are summarized in Table 7 (Reisinger and Turner, 1999; Brentler, 1990). Table 7 shows that all the fit indices meet or close to the required level. For example, the CFI, IFI, NFI and RFI are all above the cutting value of 0.90 (Brentler, 1990). Both RMSEA and $\chi^{2} / \mathrm{df}$ slightly exceed the threshold requirements, suggesting overall model fit of the structural model is good.

*** Please Insert Table 7 Here***

With the overall fit of the structural model established, the individual parameter/paths within the model were then evaluated. The hypotheses were tested by evaluating the 
relationships between the exogenous and endogenous variables. Both the signs of the parameters and the magnitudes of the estimated parameters were examined. Table 8 presents the standardized path coefficients and t-values of all of the hypothesized relationships in the model. The signs of the coefficients indicate whether the two variables were moving in the same or opposite directions, and the t-value indicates whether the corresponding path coefficient was significantly different from zero. Coefficients with t-values above +1.96 or below -1.96 are considered to be statistically significant.

***Please Insert Table 8 Here***

As shown in Table 8, the six paths test statistics are significant, suggesting that all six hypotheses are supported. The coefficient between Leader-Member Exchange and OCB-O is $0.17(\mathrm{t}=4.06)$, suggesting a significant positive relationship between the two. The strength of the relationship is moderate. The coefficient between Coworker Exchange and OCB-I is 0.22, suggesting a significant positive relationship between the two, and the strength of the relationship is moderate. The coefficient between Customer-Employee Exchange and OCB-C is 0.23, suggesting a significant positive relationship between the two, and the strength of the relationship is moderate.

The coefficient between Customer-employee Exchange and OCB-O is 0.80, suggesting a strong significant positive relationship between the two. The coefficient between LeaderMember exchange and OCB-I is 0.58, suggesting a strong significant positive relationship between the two. This also supported the researcher's assumption that various social exchanges and OCBs are inter-correlated. Positive exchanges could influence other types of OCBs rather than only influence that specific target of social exchange. The coefficient between OCB-I and OCB-C is 0.68 , suggesting a strong significant positive relationship between the two. This 
suggests that employees who perform OCBs targeting coworkers may expand these behaviors to customers.

The model suggested that social exchanges are significant motivators for employees to engage in the three types of OCBs. Different exchanges influence each type of OCBs differently, but in general, positive social exchanges positively influence employees' engagement in all three types of OCBs. The three types of OCBs seem also inter-correlated with each other. The model with the supported hypotheses is shown in Figure 4.

$$
\text { ***Please Insert Figure } 4 \text { Here }{ }^{* * *}
$$

\section{Conclusions and Implications}

\subsection{The Three-dimensional Framework of OCB}

Creating satisfied customers in the hotel industry requires exceeding customers' expectations on a constant basis. This requires employees to perform citizenship behaviors to customers in order to satisfy customers with high quality service. Therefore, OCB is closely related to the service challenges of the hotel industry, and understanding OCB and its antecedents is important for the effective functioning of hotels.

Due to the unique nature of the hotel industry where service is the major "product" that is sold to customers, OCB in the hotel setting requires special attention to service related dimensions (Borman and Motowidlo, 1993). Building on previous findings (Williams and Anderson, 1991; Bettencourt \& Brown, 1997; Bettencourt, Gwinner and Meuter, 2001) and integrating the nature of service interactions in the hotel industry, this study proposed a new three-dimensional framework of OCB using the targets of OCB as the criteria of categorization. The three dimensions include: OCB-O (to organization), OCB-I (to employee) and OCB-C (to 
customers). The Confirmatory Factor Analysis of the three-dimensional framework showed that this model has a good overall fit, good factor loadings, and construct validity. Therefore, the result of the study supports that the three-dimensional framework of OCB in the hotel setting proposed by this study is valid.

This finding is very significant because it provided a more meaningful measurement framework of OCB in the service industry, with a particular emphasis for the hotel industry. This is especially important as OCB studies have gained popularity in the hospitality discipline recently. The three-dimensional framework may also be applied in other industries where service is an important component, such as the restaurant and airline industries. By adding service components of OCB (OCB-C) into the previous identified OCB-O and OCB-I framework, this study helped to fill in the gap in previous literature and provide a more precise and specific framework of OCB for the hospitality industry.

\subsection{The Expanded Social Exchange Theory}

Social exchange theory is widely applied to explain the incidence of OCB. This study expanded social change theory first by applying it to the hospitality industry. Further, the study expanded social exchange theory by including the interactions between coworkers and the interactions between customers and employees both as social exchange processes motivating OCBs. This expansion is driven, in part, by the unique nature of the hospitality industry and the broader service context. The hospitality industry is a labor intensive industry, where many interactions happen between leaders and members (Leader-Member Exchange) and between coworkers (Coworker Exchange) on a daily basis. In addition, hospitality is also called "the People’s Industry”, where "ladies and gentlemen serve ladies and gentlemen” (Ritz Carlton 
Motto), and employees interact constantly with customers through service delivery. The relationship marketing literature has started to regard the interaction between employees and customers as an important channel of long-term relationship building. Therefore, it would be very meaningful to regard this interaction process as a social exchange process (CustomerEmployee Exchange) that is central to the creation of high quality service in hotels.

The findings of this study support the proposed expansion of social exchange theory, as each type of social exchange was a significant indicator for the particular OCB linked to the target equivalent to the exchange. Therefore, treating the customer-employee interaction process and coworkers' interaction process as a social exchange process expanded social exchange theory in a way that is both internally consistent and theoretically meaningful, as well as of practical import within the hotel industry.

In addition, social exchange with leaders is also positively related to OCBs to coworkers, and social exchange with customers is positively related to OCBs to the organization. This may suggest that positive social exchanges in a general sense can motivate employees to go above and beyond their role requirements. The implication for hotel managers is to pay attention not only to the social exchange of "insiders", but also to the exchange between "insiders" and "outsiders". Managers should care about their employees and know if their services are appreciated by the customers, because that can influence the employees' motivation in performing OCBs in a general sense. The study also finds that OCB-I is positively related to OCB-C. This suggests that if an employee is motivated to help coworkers, or is engaged within a positive team culture where helping behaviors are reciprocated, he/she probably would carry over citizenship behaviors in ways that help customers. The implication for hotels is to encourage employees to help each other and build team spirit. This can help to foster a "helping" 
atmosphere, so that going above and beyond can become a common practice for the hotels. In this way, it is not difficult to exceed customers' expectations on an ongoing basis.

\section{Limitations and Future Research}

This is a cross-sectional study with attendant limitations on causal assertions. The research was conducted in the context of China's hotel industry, and although OCB instruments and research are well-established in China, some cautions with regards to cultural norms and helping behaviors may obtain. In all contexts, employees’ self-reported data is unlikely to be free of social desirability bias (Testa, 2008; O’Reilly and Chatman, 1986).

Although the three-dimensional framework is developed based on previous research efforts, test-retest reliability for the instrumentation is desirable, and future research may wish to specifically assess cross-cultural robustness, possibly within the context of a multi-national hotel.

As a relatively new and inter-disciplinary field of study, the hospitality subject often "borrows" theories from other disciplines (Ma and Law, 2009). This allows hotel management scholars to both recognize a unique context and adapt and develop the existing knowledge to better suit our field's features. In this way, we are enriching and contributing to the existing literature. Although OCB research has been established for more than two decades, it is still not commonly applied to the challenges of the hospitality field. At this stage, a new framework on OCB that addresses the needs of this industry is highly desirable. Through this empirical and theoretical work, the authors provide new insights into OCB, social exchange and the possibilities of enhancing service performance in hospitality organizations. 


\section{Reference}

Baker,T. L., Hunt, T. G., \& Andrews, M. C. (2005). Promoting ethical behavior and organizational citizenship behaviors: the influence of corporate ethical values. Journal of Business Research, 59, 849-857.

Bateson. J. E. G. (1977). Do we need service marketing? In Marketing Consumer Services: New Insights. Cambridge, MA: Marketing Science Institute, Report \#77-115.

Bateman, T.S., \& Organ, D.W. (1983). Job satisfaction and the good solider: The relationship between affect and employee “citizenship”. Academy of Management Journal, 26, 587595.

Bettencourt, L.A., \& Brown, S.W. (1997). Contact employees: relationships among workplace fairness, job satisfaction and prosocial service behaviors. Journal of Retailing, 73, 3961.

Bettencourt, L.A., Gwinner, K. P. \& Meuter, M. L. (2001). A comparison of attitude, personality, and knowledge predictors of service-oriented organizational citizenship behaviors. Journal of Applied Psychology, 86 (1), 29-41.

Bienstock, C. C., Demoranville, C. W., \& Smith, R. K. (2003). Organizational citizenship behavior and service quality. The Journal of Service Marketing, 17 (4/5), 357.

Blau, P.M. (1986). Exchange and Power in Social Life. New Brunswick, NJ: Wiley \& Sons, Inc.

Borman, W. C., \& Motowidlo, S. J. (1993). Expanding the criterion domain to include elements to contextual performance. In N. Schmitt and W.C. Borman (Eds.), Personnel selection in organizations (pp. 71-98). San Francisco: Jossy-Bass.

Booms, B.H., \& Bitner, M.J. (1981). Marketing strategies and organization structure for service Firms. In Marketing of Services, J. Donnelly and W. George, eds., Chicago: American 
Marketing, 47-51.

Brentler, P. M. (1990). Comparative fit indexes in structural models. Psychological Bulletin, 238-246.

Brislin, R.W. (1976). Comparative research methodology: cross-cultural studies. International Journal of Psychology, 11(3), 215-229.

Carmen, J. M., \& Langeard, E. (1980). Growth strategies of service firms. Strategic Management Journal, 1, 7-22.

Cho, S., \& Johanson, M. (2008). Organizational citizenship behavior and employee performance: moderating effect of work status in restaurant employees. Journal of Hospitality and Tourism Research, 32, 307.

Chonko, L. B., \& Hunt, S. D. (1985). Ethics and marketing management: an empirical examination. Journal of Business Research, 13, 339-59.

Churchill, G.A. Jr., \& Brown, T. J. (2007). Basic Marketing Research. Mason, OH: Thomson Higher Education.

Diamantopoulos, A. \& Siguaw, J. A. (2000). Introducing LISREAL. London: Sage Publications.

Eisenberger, R., Huntington, R., Hutchison, S., \& Sowa, D. (1986). Perceived Organizational support. Journal of Applied Psychology, 71(3), 200-507.

Elanain, H. M. A. (2007). The Five-factor model of personality and organizational citizenship behavior in United Arab Emirates. SAM Advanced Management Journal, Summer.

Euwenma, M. C., Wendi, H., \& Emmerik, H. V. (2007). Leadership styles and group organizational citizenship behavior across cultures. Journal of Organizational Behavior, 28, 1035-1057.

Farth, J. L., Earley, P. C., \& Lin, S. C. (1997). Impetus for extraordinary action: A cultural 
analysis of justice and extra-role behavior in Chinese society. Administrative Science Quarterly, 42, 421-444.

Ford, R. C., \& Richardson, W. D. (1994). Ethical decision making: a review of the empirical Literature. Journal of Business Ethics 13, 205-221.

Fornell, C., \& Larcker, D. F. (1981). Evaluating structural equation models with unobservable variables and measurement error. Journal of Marketing Research, 18 (February), 39-50.

Graen, G. B., \& Uhl-Bien, M. (1995). Relationship-based approach to leadership: Development of leader-member exchange (LMX) theory of leadership over 25 years: Applying a multi-level multi-domain perspective. Leadership Quarterly, 6(2), 219-247.

Graham, J. W. (1989). Organizational Citizenship Behavior: Construct redefinition, operationalization, and validation. Unpublished working paper, Loyola University of Chicago.

Hair, J. F., Anderson, R. E., Tatham, R. L., \& Black W. C. (2006). Multivariate Data Analysis (6th ed.) Upper Saddle River, NJ: Prentice Hall.

Homans (1958). Social Exchange Theory. Retrieved from http://www.fsc.yorku.ca/york/istheory/wiki/index.php/Social_exchange_theory

Holmes, J. G. (1981). The exchange process in close relationships: microbehavior and Macromotives, in Lerner, J.M., Lerner, C.S. (Eds). The Justice Motive in Social Behavior, New York, NY: Plenum.

Ilies, R., Nahrgang, J. D., \& Morgeson, F. P. (2007). Leader-member exchange and citizenship behaviors: A meta-analysis. Journal of Applied Psychology, 92, 269-277.

Konovsky, M.A., \& Organ, D.W (1996). Dispositional and contextual determinants of organizational citizenship behavior. Journal of Organizational Behavior, 17.253-266. 
Konovsky, M., \& Pugh, D. S. (1994). Citizenship behavior and social exchange. Academy of Management Journal, 37, 656-669.

Ladd, D., \& Henry, R. (2000). Helping coworkers and helping the organization: the role of support perceptions, exchange ideology, and conscientiousness. Journal of Applied Social Psychology, 30 (10), 2028-2049.

Lawler, E. J. (2001). An affect theory of social exchange. The American Journal of Sociology, 10 (2), 321-52.

Lerman, D. (2006). Consumer politeness and complaining behavior. Journal of Services Marketing, 20 (2), 92 - 100.

Law, K. S., Wong, C. S., \& Chen, Z. X. (2005). The construct of organizational citizenship behavior: Should we analyze after we have conceptualized? In: Turnipseed (Ed.), Handbook of Organizational Citizenship Behavior, 47-65. New York, NY: Nova Science Publishers, Inc.

Lazer, W., \& Layton, R. (1999). Quality of Hospitality Service: A Challenge for the Millennium. Retrieved from http://www.hotel-online.com/Trends/EI/EI_ServiceChallenge.html

LePine, J. A., Erez, A., \& Johnson, D. E. (2002). The nature and dimensionality of organizational citizenship behavior: a critical review and meta-analysis. Journal of Applied Psychology, 87, 52-65.

Lin, C., Hung, W., \& Chiu, C. (2008). Being good citizens: Understanding a mediating mechanism of organizational commitment and social network ties in OCBs. Journal of Business Ethics, 81, 561-578.

Lovelock, C. H. (1981). Why marketing management need to e different for services, in Marketing of Sciences, J. Donelly and W. George, Eds., Chicago: American Marketing, 5-9. 
Ma, E. \& Law, R. (2009). Identifying the Components of Tourism Research: Evidence from the Annals of Tourism Research. Anatolia: An International Journal of Tourism and Hospitality Research, 20 (1), 62-74.

Moorman, R.H., \& Blakely, G.L., (1995). Individualism collectivism as an individual difference predictor of organizational citizenship behavior. Journal of Organizational Behavior, 16(2). 127-142.

Nunnally, J. C. \& Bernstein, I. H. (1994).Psychometric Theory (3rd ed.). New York, NY: McGraw-Hill.

O’Reilly, C. A., \& Chatman, J., (1986). Organizational commitment and psychological attachment: the effects of compliance, identification, and internationalization on prosocial behavior. Journal of Applied Psychology, 3, 492-499.

Organ, D. W. (1988). Organizational citizenship behavior: The Good Soldier Syndrome. Lexington, MA: Lexington Books.

Organ, D. W., Podsakoff, P. M., \& MacKenzie, S. B. (2006). Organizational Citizenship Behavior. Its Nature, Antecedents, and Consequences. Thousand Oaks, CA: Sage. Parasuranan, A., Berry, L. L. \& Zeithaml, V. A. (1988). SERVQUAL: A multiple-item scale for measuring customer perceptions of service quality. Journal of Retailing, 64 (1), 12-40.

Podsakoff, P. M., \& MacKenzie, S. B. (1997). Impact of organizational citizenship behavior on organizational performance: A review and suggestions for future research. Human Performance, 10, 133-151.

Podsakoff, P. M., MacKenzie, S. B., Moorman, R. H., \& Fetter, R. (1990). Transformational leadership behavior and their effects on followers’ trust in leader, satisfaction, and organizational citizenship behaviors. Leadership Quarterly, 1, 107-142.

Podsakoff, P. M., MacKenzie, S. B., Paine, J. B., \& Bachrach, D. G. (2000). Organizational 
citizenship behaviors: A critical review of the theoretical and empirical literature and suggestions for future research. Journal of Management, 26, 513-563.

Rhodes, L., \& Eisenberger, R. (2002). Perceived organizational support: A review of the literature. Journal of Applied Psychology, 87, 698-714.

Reisinger, Y., \& Turner, L. (1999). Structured equation modeling with LISREL: An application in tourism. Tourism Management, 20, 71-88.

Research and Market (2008). Global lodging industry: China's hotel market to drive growth, Retrieved from http://www.researchandmarkets.com/reportinfo.asp?report_id=590273

Scott, K. D. (2007). The development and test of an exchange-based model of interpersonal workplace exclusion. Ph.D. Dissertation, University of Kentucky, Lexington.

Sierra, F. F., \& McQuitty, S. (2005). Service providers and customers: social exchange theory and service loyalty. Journal of Services Marketing, 19 (6), 392-400.

Smith, C. A., Organ, D. W., \& Near J. P. (1983). Organizational citizenship behavior: Its nature and antecedents. Journal of Applied Psychology, 68, 653-663.

Stevens, J. P. (2002). Applied multivariate statistics for the social sciences, Mahwah, New Jersey: Lawrence Erlbaum Associates.

Testa, M. R. (2009). National Culture, leadership and citizenship: Implications for crosscultural management. International Journal of Hospitality Management, 28 (1), 78-85.

Tsui, A. S., Pearce, J. L., Porter, L. W., \& Tripoli, A. M. (1997). Alternative approaches to the employee-organization relationship: Does investment in employees pay off? Academy of Management Journal, 40(5), 1089-1121.

Tsui, A. S., \& Wu, J. B. (2005). The employment relationship versus the mutual investment 
approach: Implications for human resource management. Human Resource Management, 44(2), 115-121.

Van Dyne, L., \& Ang, S. (1998). Organizational citizenship behavior of contingent workers in Singapore. Academy of Management Journal, 41(6), 692-703.

Van Dyne, L., Cummings, L.L., \& McLean Parks, J.M. (1995). Extra-role behaviors: In pursuit of construct and definitional clarity (A bridge over muddied waters). In L.L. Cummings \& B.M. Staw (Eds.), Research in Organizational Behavior, 17: 215-285. Greenwich: JAI Press.

Williams, L. J., \& Anderson, S.E. (1991) 'Job Satisfaction and Organizational Commitment as Predictors of Organizational Citizenship and In-Role Behaviors. Journal of Management, 17, 601-17.

Zeithaml, V. (1987), Defining and Relating Price, Perceived Quality, and Perceived Value, Report No, 87-101, Cambridge, MA: Marketing Science Institute. 


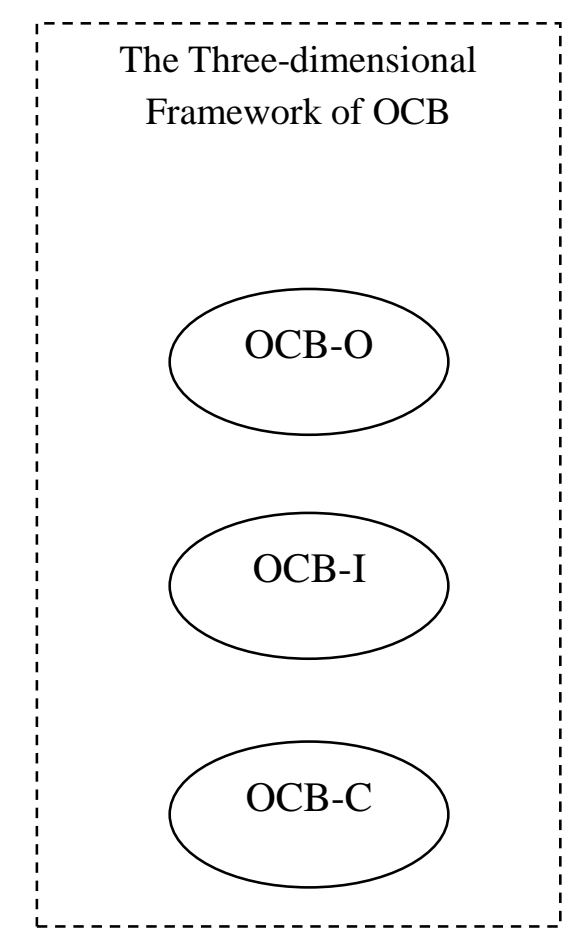

Figure 1 The Three-dimensional Framework of OCB 


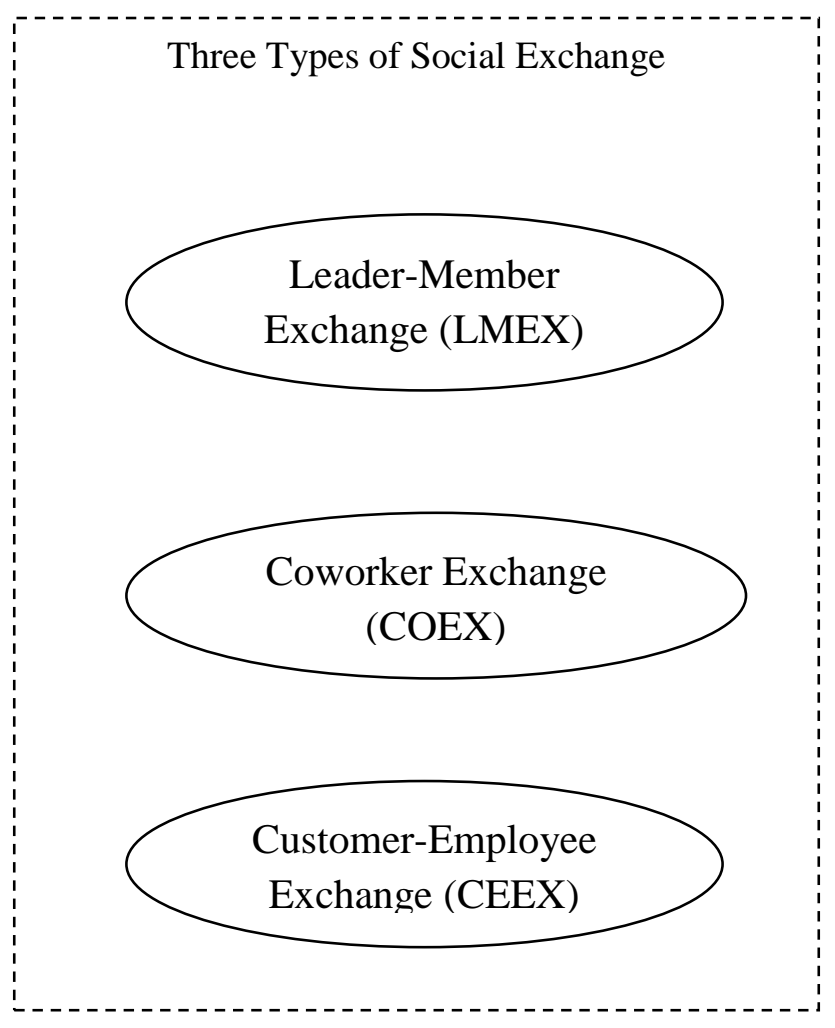

Figure 2 The Three Types of Social Exchange in the Hotel Context 


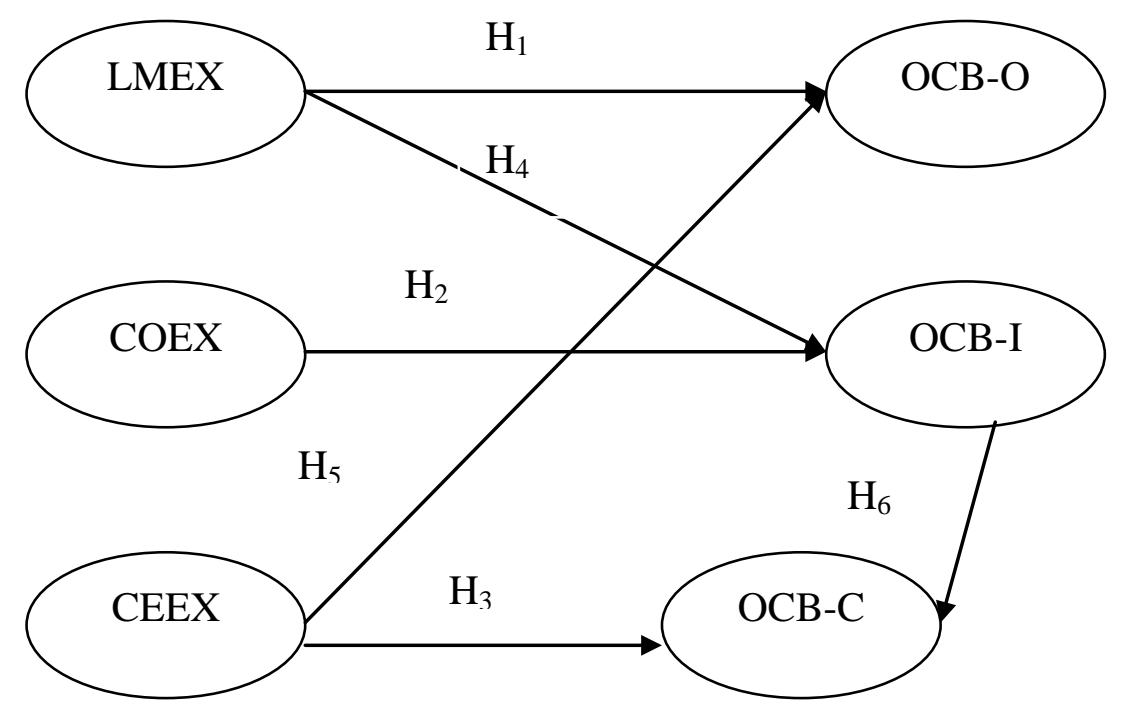

Figure 3 The Conceptual Model and Hypotheses 
Table 1 Cronbach's Alpha for the Latent Constructs

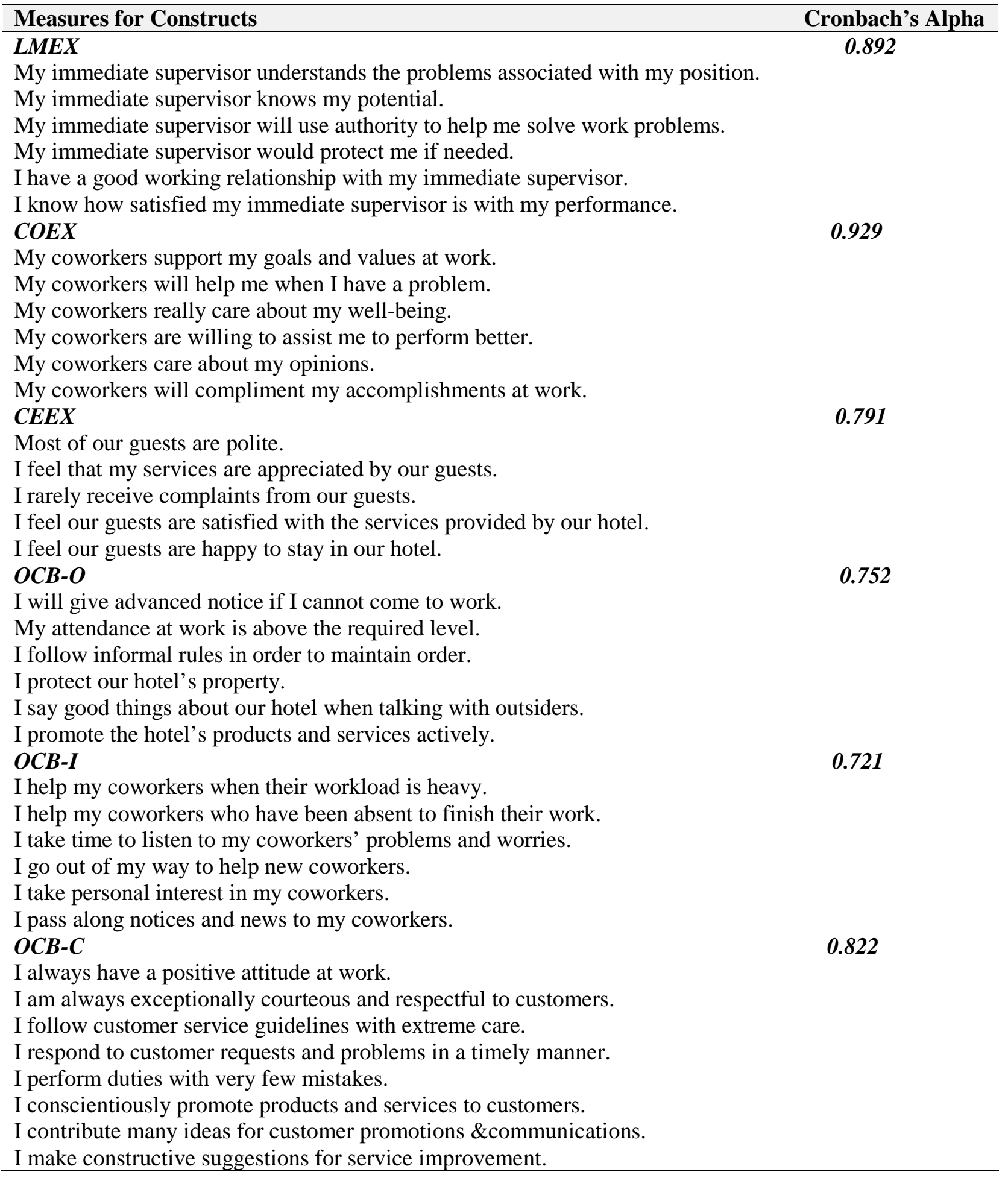


Table 2 Demographic Profile and Work-related Information of Participants

\begin{tabular}{|c|c|c|c|}
\hline $\begin{array}{l}\text { Demographic } \\
\text { Characteristic } \\
\end{array}$ & Frequency (\%) & $\begin{array}{l}\text { Work-related } \\
\text { Characteristics }\end{array}$ & Frequency (\%) \\
\hline Gender & & Employment & \\
\hline Male & $123(30.2)$ & Full Time & $67(16.5)$ \\
\hline Female & $266(65.4)$ & Part Time & $323(79.4)$ \\
\hline Missing & $18(4.4)$ & Missing & $17(4.2 \%)$ \\
\hline Age & & Position & \\
\hline $18-29$ & $231(56.8)$ & Entry Level & 210 (51.6) \\
\hline 30-39 & $93(22.9)$ & Supervisory & $197(48.4)$ \\
\hline $40-49$ & $63(15.5)$ & Missing & $0(0)$ \\
\hline $50-59$ & $13(3.2)$ & & \\
\hline$\geq 60$ & $1(.20)$ & Department & \\
\hline \multirow[t]{2}{*}{ Missing } & $6(1.5)$ & Front Desk & $42(10.3)$ \\
\hline & & Housekeeping & $122(30.0)$ \\
\hline Ethnicity & & Food \& Beverage & $53(13.0)$ \\
\hline Caucasian & $0(0)$ & Human Resource & $42(10.3)$ \\
\hline African American & $0(0)$ & Sales \& Marketing & $28(6.9)$ \\
\hline Hispanic & $0(0)$ & Finance & $26(6.4)$ \\
\hline Asian & $407(100)$ & Engineering & $22(5.4)$ \\
\hline Others & $0(0)$ & Others & $9(2.2)$ \\
\hline Missing & $0(0)$ & Missing & $63(15.5)$ \\
\hline Education & & Length of Working & \\
\hline Less than High School & $53(13.0)$ & Less than 1 year & $132(32.4)$ \\
\hline High School & $129(31.7)$ & 1 to 3 years & $131(32.2)$ \\
\hline 2-year College & $110(27.0)$ & 4 to 6 years & $56(13.8)$ \\
\hline 4-year College & $95(23.3)$ & 7 to 10 years & $22(5.4)$ \\
\hline Graduate School & $14(3.4)$ & More than 10 years & $58(14.3)$ \\
\hline Missing & $6(1.5)$ & Missing & $8(2.0)$ \\
\hline
\end{tabular}


Table 3 Mean, Standard Deviation and Correlations of Demographic Variables

\begin{tabular}{lllllll}
\hline Variables & Mean (SD) & $\begin{array}{l}\text { Length } \\
\text { of Work }\end{array}$ & Gender & Age & Education & Income \\
\hline Length of work & $2.36(1.37)$ & 1.000 & & & & \\
Gender & $0.32(0.47)$ & .049 & 1.000 & & & \\
Age & $1.65(0.88)$ & $.660^{* *}$ & .095 & 1.000 & & \\
Education & $2.72(1.07)$ & -.024 & .089 & -.098 & 1.000 & \\
Income & $2.53(1.20)$ & $.329^{* *}$ & $.120^{*}$ & $.282^{* *}$ & .102 & 1.000 \\
\hline
\end{tabular}


Table 4 Mean, Standard Deviation and Correlations of the Latent Constructs

\begin{tabular}{lllllllll}
\hline Constructs & $\begin{array}{l}\# \text { of } \\
\text { Items }\end{array}$ & Mean (SD) & LMEX & COEX & CEEX & OCBO & OCBI & OCBC \\
\hline LMEX & 6 & $5.30(1.03)$ & 1.000 & & & & \\
COEX & 6 & $5.51(0.90)$ & $.634^{* *}$ & 1.000 & & & \\
CEEX & 5 & $5.50(0.87)$ & $.520^{* *}$ & $.629^{* *}$ & 1.000 & & & \\
OCBO & 6 & $5.98(0.69)$ & $.328^{* *}$ & $.413^{* *}$ & $.448^{* *}$ & 1.000 & & \\
OCBI & 6 & $5.90(0.72)$ & $.434^{* *}$ & $.526^{* *}$ & $.518^{* *}$ & $.677^{* *}$ & 1.000 & \\
OCBC & 8 & $5.81(0.73)$ & $.487^{* *}$ & $.518^{* *}$ & $.606^{* *}$ & $.641^{* *}$ & $.752^{* *}$ & 1.000 \\
\hline$* *$ Significant at $\mathrm{P}<0.01$ Level & & & & & &
\end{tabular}


Table 5 The Fit Indices of the OCB Dimension

\begin{tabular}{|l|l|l|}
\hline $\boldsymbol{\chi}^{\mathbf{2}}$ with degrees of freedom & $\mathbf{1 1 5 9 . 4 6}(\mathbf{P}=\mathbf{0 . 0})$ with 186 df & Fit Guidelines \\
\hline$\chi^{2} / \mathrm{df}$ & 6.23 & 2.0 to 5.0 \\
\hline RMSEA & 0.12 & $<0.10$ \\
\hline SRMR & 0.061 & $<0.08$ \\
\hline CFI & 0.95 & $\geq 0.9$ \\
\hline IFI & 0.95 & $\geq 0.9$ \\
\hline NFI & 0.94 & $\geq 0.9$ \\
\hline RFI & 0.93 & $\geq 0.9$ \\
\hline
\end{tabular}


Table 6 The Loadings, CR and Ave Values of the Three-dimensional Framework of OCB

\begin{tabular}{|c|c|c|c|c|}
\hline & Loadings & T-values & $\mathbf{C R}$ & AVE \\
\hline OCB-O & & & 0.89 & 0.58 \\
\hline I will give advanced notice if I cannot come to work. & 0.51 & 9.10 & & \\
\hline My attendance at work is above the required level. & 0.56 & 10.15 & & \\
\hline I follow informal rules in order to maintain order. & 0.63 & 11.89 & & \\
\hline I protect our hotel’s property. & 0.74 & 14.70 & & \\
\hline I say good things about our hotel when talking with outsiders. & 0.79 & 16.07 & & \\
\hline I promote the hotel’s products and services actively. & 0.78 & 15.66 & & \\
\hline OCB-I & & & 0.94 & 0.66 \\
\hline I help my coworkers when their workload is heavy. & 0.69 & 13.60 & & \\
\hline I help my coworkers who have been absent to finish their work. & 0.77 & 15.84 & & \\
\hline I take time to listen to my coworkers’ problems and worries. & 0.79 & 16.42 & & \\
\hline I go out of my way to help new coworkers. & 0.80 & 16.59 & & \\
\hline I take personal interest in my coworkers. & 0.76 & 15.62 & & \\
\hline I pass along notices and news to my coworkers. & 0.80 & 16.74 & & \\
\hline$O C B-C$ & & & 0.94 & 0.68 \\
\hline I always have a positive attitude at work. & 0.67 & 13.10 & & \\
\hline I am always exceptionally courteous and respectful to customers. & 0.81 & 17.13 & & \\
\hline I follow customer service guidelines with extreme care. & 0.86 & 18.64 & & \\
\hline I respond to customer requests and problems in a timely manner. & 0.79 & 16.49 & & \\
\hline I perform duties with very few mistakes. & 0.71 & 14.17 & & \\
\hline I conscientiously promote products and services to customers. & 0.72 & 14.46 & & \\
\hline I contribute many ideas for customer promotions \&communications. & 0.70 & 13.88 & & \\
\hline I make constructive suggestions for service improvement. & 0.66 & 12.93 & & \\
\hline
\end{tabular}


Table 7 The Fit Indices of the Structural Model

\begin{tabular}{|c|c|c|}
\hline$\chi^{\mathbf{2}}$ with degrees of freedom & $\mathbf{3 4 7 8 . 6 8}(\mathbf{P}=\mathbf{0 . 0})$ with 656 df & Fit Guidelines \\
\hline$\chi^{2} / \mathrm{df}$ & 5.30 & 2.0 to 5.0 \\
\hline RMSEA & 0.11 & $<0.10$ \\
\hline SRMR & 0.089 & $<0.10$ \\
\hline CFI & 0.93 & $\geq 0.9$ \\
\hline IFI & 0.93 & $\geq 0.9$ \\
\hline NFI & 0.92 & $\geq 0.9$ \\
\hline RFI & 0.91 & $\geq 0.9$ \\
\hline Constructs & CR Values & AVE Values \\
\hline Leader-member Exchange & 0.89 & 0.54 \\
\hline Coworker Exchange & 0.93 & 0.70 \\
\hline Customer-employee Exchange & 0.87 & 0.57 \\
\hline OCB-O & 0.85 & 0.43 \\
\hline OCB-I & 0.89 & 0.59 \\
\hline OCB-C & 0.89 & 0.58 \\
\hline
\end{tabular}


Table 8 Summary of the Hypothesis Testing

\begin{tabular}{|c|c|c|c|c|}
\hline Hypotheses & Path & Std. coefficient & t-value & Result \\
\hline H1 & LMEX $\longrightarrow$ OCB-O & 0.17 & 4.06 & Supported \\
\hline H2 & COEX $\longrightarrow$ OCB-I & 0.22 & 3.71 & Supported \\
\hline H3 & CEEX $\longrightarrow$ OCB-C & 0.23 & 4.76 & Supported \\
\hline H4 & CEEX $\longrightarrow$ OCB-O & 0.80 & 14.11 & Supported \\
\hline H5 & LMEX $\longrightarrow$ OCB-I & 0.58 & 7.18 & Supported \\
\hline H6 & OCB-I $\longrightarrow$ OCB-C & 0.68 & 7.71 & Supported \\
\hline
\end{tabular}




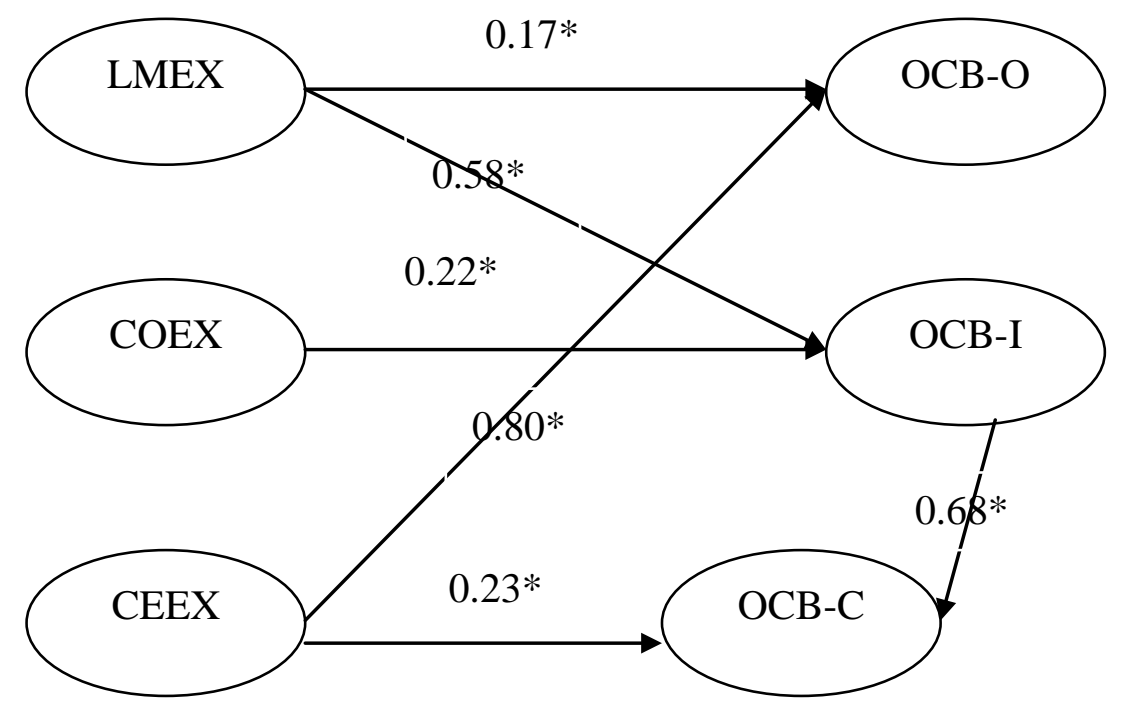

Figure 4 The Structural Model with Standardized Coefficients (*: Significant at $\mathrm{P}<.05$ ) 